\title{
Penerapan Metode Demontrasi Berbantuan Media Sederhana untuk Meningkatkan Hasil Belajar Tematik (Muatan Matematika)
}

\section{Ni Nyoman Sukerti ${ }^{*}$}

${ }^{1}$ SD Negeri 2 Kampung Baru, Singaraja, Indonesia

\section{A R T I C L E I N F O}

Article history:

Received 15 February 2021

Received in revised form 27 March 2021

Accepted 10 April 2021

Available online 11 May 2021

Kata Kunci:

Metode Demonstrasi,

Hasil Belajar, Matematika.

Keywords:

Demonstration Methods, Learning Outcomes,

Mathematics.

\begin{abstract}
A B S T R A K
Berdasarkan hasil observasi dan tes awal memperoleh hasil rendahnya hasil belajar tematik (muatan matematika), sehingga diperlukan metode dan media yang dapat meningkatkan hasil belajar siswa. Penelitian ini bertujuan untuk menganalisis penerapan metode demontrasi berbantuan media sederhana terhadap hasil belajar tematik (muatan matematika) siswa kelas III SD. Penelitian ini termasuk kedalam jenis penelitian tindakan kelas (PTK). Subjek penelitian ini adalah hasil belajar muatan matematika, sedangkan objek penelitian yang digunakan adalah siswa kelas III yang jumlahnya 15 orang. Metode yang digunakan dalam pengumpulan data adalah metode tes dengan instrumen berupa lembar tes pilihan ganda. Data dianalisis menggunakan teknik analisis data statistik deskriptif kuantitatif. Hasil penelitian ini memperoleh peningkatan hasil belajar siswa yaitu pra siklus sebesar $64,00 \%$ yang tergolong kurang, siklus I sebesar $73,33 \%$ yang tergolong cukup dan meningkat pada siklus II sebesar $78,67 \%$ yang tergolong baik. Sehingga dapat disimpulkan bahwa penerapan metode demonstrasi berbantuan media
\end{abstract} sederhana dapat meningkatkan hasil belajar tematik (muatan Matematika) siswa kelas III SD. Implikasi penelitian ini adalah dapat membuat pengajaran menjadi lebih jelas dan lebih konkret, siswa lebih mudah memahami materi, proses pengajaran lebih menarik, siswa dirangsang untuk aktif mengamati, menyesuaikan antara teori dengan kenyataan dan melatih siswa untuk berani mencoba.

\begin{abstract}
A B S T R A K
Based on the results of observations and preliminary tests, the results of thematic learning (mathematics content) are low, so we need methods and media that can improve student learning outcomes. This study aims to analyze the application of the demonstration method assisted by simple media on the thematic learning outcomes (math content) of third grade elementary school students. This research belongs to the type of classroom action research (PTK). The subjects of this study were the results of learning mathematics content, while the object of the study was 15 grade students. The method used in data collection is the test method with instruments in the form of multiple choice test sheets. Data were analyzed using quantitative descriptive statistical data analysis techniques. The results of this study obtained an increase in student learning outcomes, namely pre-cycle by $64.00 \%$ which is classified as less, in the first cycle of $73.33 \%$ which is classified as sufficient and increased in the second cycle by $78.67 \%$ which is classified as good. So it can be concluded that the application of the demonstration method assisted by simple media can improve the thematic learning outcomes (Mathematics content) of third grade elementary school students. The implication of this research is that it can make teaching clearer and more concrete, students understand the material easier, the teaching process is more interesting, students are stimulated to actively observe, adjust theory to reality and train students to dare to try.
\end{abstract}




\section{Pendahuluan}

Salah satu tujuan pendidikan di sekolah dasar khususnya adalah membantu siswa memahami masalah-masalah yang terjadi di lingkungan sekitar siswa atau dalam kehidupan sehari-hari. Dalam berbagai jenjang pendidikan diajarkan mata pelajaran tertentu yang dapat memberikan pengetahuan, sehingga dapat dijadikan acuan dalam menghadapi permasalahan dalam kehidupan sehari-hari. Matematika adalah salah satu mata pelajaran berkesinambungan yang diajarkan dalam setiap jenjang pendidikan mulai dari sekolah dasar sampai perguruan tinggi. (Anisah \& Lastuti, 2018; Handayani et al., 2014; Putri et al., 2020) menyatakan, pelajaran Matematika khususnya di sekolah dasar diajarkan dengan tujuan memberikan konsep awal kepada siswa untuk mempelajari Matematika pada jenjang yang lebih tinggi.

Ketidakberhasilan mempelajari Matematika dipengaruhi oleh kesulitan guru dalam mengelola dan menyampaikan materi ajar sehingga menghasilkan ketidakkebermaknaan belajar bagi para siswa (Latifah \& Nurlaeli, 2017; Nurhazannah, 2017; Rahmadani et al., 2018). Mengingat hal itu, mempelajari Matematika dianggap sulit, menjadi salah satu mata pelajaran yang membosankan, ditakuti dan kurang diminati siswa. Dalam mengikuti proses pembelajaran Matematika, siswa sering melakukan aktivitas lain di dalam kelas, misalnya ada siswa yang menggambar atau mencoret-coret buku pelajaran dan bahkan mengganggu temannya yang sedang serius mengikuti pelajaran.

Banyak faktor yang menyebabkan mata pelajaran Matematika kurang diminati oleh siswa, diantaranya adalah pembelajaran terlalu berpusat ke guru, siswa hanya berperan sebagai pendengar dan penerima semua informasi yang diberikan oleh guru. Faktor lain karena banyak guru yang enggan atau malas menggunakan media atau alat peraga dalam menyampaikan materi pelajaran, terlebih lagi jika media atau alat peraga tersebut tidak tersedia di sekolah. Padahal media pembelajaran sangat berperan membantu siswa dalam memahami suatu konsep. Hal ini sejalan dengan pendapat (Cahyaningsih, 2018; Dewiyanti, 2018; Elinawati et al., 2018), yang menyatakan bahwa dalam proses belajar anak sebaiknya diberi kesempatan memanipulasi benda-benda atau alat peraga yang dirancang secara khusus dan dapat diotak-otik oleh siswa dalam memahami suatu konsep. Melalui media konsep-konsep yang diajarkan melekat dengan baik diingatan siswa dan berpengaruh terhadap hasil belajar siswa.

Berdasarkan hasil observasi dan diperolehnya hasil tes awal hasil belajar Matematika siswa kelas III SD Negeri 2 Kampung Baru diperoleh rata-rata hasil belajar siswa sebesar 64,00 yang berada pada kategori cukup. Rendahnya hasil belajar Matematika siswa dipengaruhi oleh beberapa hal, diantaranya: (1) siswa belum bisa menemukan apa yang menjadi permasalahan dalam soal; (2) jika diberikan soal yang berbeda dari contoh, siswa tidak bisa mengerjakannya; (3) siswa belum dapat mengaplikasikan konsep pelajaran ke dalam kehidupan mereka; (4) siswa tidak dapat menjelaskan kembali tentang konsep materi pembelajaran yang telah dipelajari; dan (5) siswa belum bisa memilih prosedur atau langkahlangkah yang harus dikerjakan terlebih dahulu dalam menjawab soal. Sesuai dengan permasalahan tersebut, perlu dilakukan perbaikan dan pembaharuan dalam pembelajaran. Salah satu alternatif dalam perbaikan metode pembelajaran yang sesuai dengan permasalahan tersebut adalah dengan menggunakan metode demonstrasi berbantuan media sederhana. Melalui metode demontrasi yang dilakukan oleh guru, siswa dapat melakukan pengamatan langsung sehingga dapat memahami materi. Dibantu dengan media sederhana yang dapat meningkatkan atau mempercepat pemahaman siswa terhadap materi. Melalui penerapan metode demonstrasi berbantuan media sederhana diharapkan hasil belajar Matematika siswa dapat meningkat.

Metode demonstrasi adalah cara penyajian bahan pelajaran dengan memperagakan atau mempertunjukkan kepada siswa suatu proses, situasi, atau benda tertentu yang sedang dipelajari baik sebenarnya maupun tiruan, yang sering disertai penjelasan lisan (Nahdi et al., 2018; Nurmitasari, 2016; Rizkiana et al., 2016). Selain itu metode demonstrasi dapat dikatakan sebagai suatu metode mengajar yang memperlihatkan tentang sesuatu disertai penjelasan lisan, siswa melihat dan mengamati sehingga memperoleh gambaran yang jelas. Tujuan penerapan metode demonstrasi adalah untuk mendapatkan gambaran yang jelas tentang hal-hal yang berhubungan dengan proses mengatur sesuatu, proses membuat sesuatu, proses bekerjanya sesuatu, proses mengeijakan atau menggunakannya, komponenkomponen yang membentuk sesuatu, membandingkan suatu cara dengan cara lain dan untuk mengetahui atau melihat kebenaran sesuatu (Annisa et al., 2014; Netriza, 2019; Purwanti, 2018).

Menurut (Andriansyah, 2020; Masduri, 2014; Srininsih, 2015) menyatakan kelebihan metode demonstrasi meliputi: (1) dapat membuat pengajaran menjadi lebih jelas dan lebih konkret, sehingga dapat menghindari verbalisme (pemahaman secara kata-kata atau kalimat); (2) siswa lebih mudah memahami apa yang dipelajari; (3) proses pengajaran lebih menarik; (4) siswa dirangsang untuk aktif mengamati, menyesuaikan antara teori dengan kenyataan dan mencoba melakukan sendiri. Metode demonstrasi akan lebih efektif digunakan jika dilengkapi dengan penggunaan media sederhana. 
Media sederhana merupakan media yang bahan dasarnya mudah diperoleh, harganya murah, pembuatannya mudah, dan penggunaannya tidak sulit (Bahtiar, 2019; Sari et al., 2019; Ulya \& Rofian, 2019). Selain itu, media sederhana dapat diartikan sebagai media pembelajaran yang memiliki perbedaan karakteristik dan tidak bisa digolongkan ke dalam pembelajaran visual ataupun audio-visual. Media sederhana tergolong murah dan tidak rumit, sehingga pengadaannya dapat dikembangkan sendiri oleh guru, walaupun begitu media pembelajaran sederhana tidak berarti lebih rendah kualitasnya dibandingkan dengan media pembelajaran yang mengunakan teknologi canggih. Ciri-ciri media sederhana yaitu: (1) dapat dengan mudah dibuat sendiri oleh guru atau bersama-sama siswa; (2) dapat dibuat dengan mengunakan bahan-bahan yang mudah di proleh di lingkungan sekitar; (3) pengunaannya dalam kegiatan pembelajaran tidak memerlukan keahlian atau teknik yang khusus; (4) bisa berbentuk dua atau tiga dimensi. Kelebihan media sederhana adalah mudah diproleh di lingkungan sekitar, lebih realistis sehinga mudah dipahami, relatif murah sehingga, mampu dikembangkan oleh sekolah (Citrasmi et al., 2016; Maufur \& Lisnawati, 2017; Ulfah \& Soenarto, 2017). Media yang dipergunakan dalam penelitian ini adalah media sederhana, karena merupakan media yang mudah diperoleh dan harganya murah, cara pembuatannya mudah, dan penggunaannya tidak sulit (Anggrain \& Veronica, 2015; Mudarini, 2017; Wicaksono et al., 2020). Di lingkungan sekolah banyak tersedia media sederhana, tetapi diperlukan kejelian guru untuk memilah dan memilih media yang tepat sesuai dengan tujuan pembelajaran. Media sederhana yang digunakan pada penelitian ini adalah kartu bilangan, kerikil, manik-manik, tangkai es krim, pensil, dan benda-benda yang ada di sekitar. Penggunaan media pembelajaran ini diharapkan dapat membantu dalam meningkatkan hasil belajar siswa.

Hasil belajar merupakan hasil yang dicapai oleh pebelajar setelah mengalami proses belajar (Asnita, 2016; Mariani, 2017; Sopia \& Wutsqa, 2015). Pendapat ini menyatakan bahwa hasil siswa juga berarti hasil guru. Dengan dihasilkannya hasil belajar siswa yang baik maka hal itu menunjukkan keberhasilan seorang guru dalam mengajar dan begitu pula sebaliknya, jika hasil belajar siswa kurang baik maka guru tersebut kurang berhasil dalam melaksanakan tugasnya. Hasil belajar menunjukkan adanya peningkatan dalam proses pembelajaran. Ada beberapa faktor yang mempengaruhi hasil belajar antara lain: (1) faktor dalam yang terdiri fisikologis yang mencakup kondisi fisik, dan panca indra, serta fisiologis yang mencakup bakat, minat, kecerdasan, motivasi, dan kemampuan kognitif; (2) faktor luar yang terdiri dari lingkungan, instrumen yang mencakup kurikulum, guru, atau guru, sarana dan prasarana, media, metode, administrasi atau manajemen (Mariani, 2017; Pramana et al., 2014; Sopia \& Wutsqa, 2015).

Penelitian tindakan kelas ini tentang penerapan metode demontrasi berbantuan media sederhana, didukung dengan beberapa penelitian sebelumnya yang relevan yaitu, pertama penelitian yang dilaksanakan oleh (Rizkiana et al., 2016), yang mendapatkan hasil bahwa praktikum dan Metode Demonstrasi dalam pembelajaran inkuiri terbimbing berpengaruh terhadap motivasi belajar siswa. Kedua, penelitian yang dilaksanakan oleh (Nahdi et al., 2018), yang mendapatkan hasil bahwa penerapan Metode Demonstrasi pada mata pelajaran IPA berpengaruh terhadap pemahaman konsep siswa. Ketiga, penelitian yang dilaksanakan oleh (Masduri, 2014), yang mendapatkan hasil adalah penerapan kolaborasi Metode Demonstrasi dan eksperimen terbukti berpengaruh terhadap pemahaman konsep sifat-sifat bangun ruang.

Tujuan penelitian ini adalah untuk menganalisis penerapan metode demontrasi berbantuan media sederhana terhadap hasil belajar tematik (muatan matematika) siswa kelas III SD Negeri 2 Kampung Baru semester I tahun pelajaran 2019/2020.

\section{Metode}

Penelitian ini termasuk kedalam penelitian tindakan kelas (PTK), yang dilaksanakan di SD Negeri 2 Kampung Baru Kecamatan Buleleng, Kabupaten Buleleng. Penelitian ini dilaksanakan dalam waktu beberapa bulan dari siklus sampai siklus selanjutnya tergantung pencapaian tujuan penelitian tepatnya pada semester ganjil tahun pelajaran 2019/2020.

Subjek penelitian ini adalah hasil belajar muatan matematika, sedangkan objek penelitian yang digunakan adalah siswa kelas III yang jumlahnya 15 orang yang terdiri dari 10 orang siswa laki-laki dan 5 orang siswa perempuan. Penelitian ini dilaksanakan melalui dua tahapan yaitu siklus I dan siklus II.

Data hasil belajar dikumpulkan dengan menggunakan metode tes. Tes adalah suatu cara untuk mengadakan penilaian yang berbentuk suatu tugas atau serangkaian tugas yang harus dikerjakan oleh anak atau sekelompok anak sehingga menghasilkan suatu nilai (Mariani, 2017; Pramana et al., 2014; Sopia \& Wutsqa, 2015). Metode ini digunakan untuk mengumpulkan data tentang hasil belajar Matematika siswa, dan alat pengumpulan data berupa lembar pilihan ganda . 
Setelah data dalam penelitian ini terkumpul maka selanjutnya dilakukan analisis data. Data hasil belajar siswa dianalisis menggunakan teknik analisis data statistik deskriptif kuantitatif. Data ini dianalisis untuk memperoleh hasil analisis penerapan metode demontrasi berbantuan media sederhana terhadap hasil belajar tematik (muatan matematika) siswa.

\section{Hasil dan Pembahasan}

Penelitian ini dimulai dari siklus I dimulai dengan perencanaan seperti: (1) mempersiapkan buku-buku untuk menyusun persiapan mengajar seperti kalender pendidikan, silabus, buku sumber, buku penunjang yang relevan serta alat tulis, (2) mempersiapkan rancangan pelaksanaan metode demonstrasi berbantuan media sederhana yang akan digunakan dalam mengajar.

Pada tahap pelaksanaan, peneliti melaksanakan semua perencanaan pembelajaran yang telah disusun. Secara garis besar pelaksanaan proses pembelajaran adalah: (1) memberikan materi pelajaran dengan menerapkan metode demonstrasi di kelas, (2) mempersiapkan alat yang diperlukan, (3) mengatur peserta didik agar mereka mudah melihat dan mengamati demonstrasi yang sedang berlangsung, (4) menjelaskan tentang tujuan demonstrasi yang handal dicapai, (5) menunjukkan langkah-langkah demonstrasi yang yang hendak dilakukan, (6) mengecek segala alat yang akan terlibat dalam demonstrasi itu, (7) mulai demonstrasi sesuai dengan langkah-langkah yang telah ditetapkan menurut rencana, (8) memperlihatkan peserta didik yang melihat jalannya demonstrasi, (9) membuka kesempatan bagi peserta didik untuk bertanya, (10) membimbing peserta didik kearah pertumbuhan sikap untuk berani melakukannya, (11) memberi kesempatan kepada peserta didik untuk mencoba melakukan demonstrasi, (12) mengambil sejumlah kesempatan dari hasil demonstrasi tersebut, (13) membuat hasil laporan demonstrasi secara tertulis, (14) mengulang kembali kegiatan yang telah dilakukan memberikan kesimpulan.

Observasi dilaksanakan untuk mengetahui hambatan atau kendala yang dialami, dan evaluasi dilaksanakan pada akhir siklus untuk mengetahui hasil tindakan yang telah dilaksanakan. Setelah kegiatan observasi/evaluasi dilakukan, peneliti mengkaji dan merenungkan hasil penelitian terhadap pelaksanaan tindakan pada siklus I dengan tujuan untuk mengetahui hambatan-hambatan atau masalah-masalah yang dialami serta memikirkan pemecahannya. Kemudian dilanjutkan pada siklus selanjutnya. Berdasarkan hasil penelitian ini dari prasiklus, siklus I, dan siklus II. Maka peneliti dapat menggambarkan rekapitulasi hasil pembelajaran dapat dilihat pada Tabel 1.

Tabel 1. Perkembangan Hasil Belajar

\begin{tabular}{llll}
\hline Uraian & Prasiklus & Siklus I & Siklus II \\
\hline Jumlah & 960 & 1100 & 1180 \\
M & 64 & 73.33 & 78.67 \\
M\% & $64 \%$ & $73.33 \%$ & $78.67 \%$ \\
Kriteria & Kurang & Cukup & Baik \\
\hline
\end{tabular}

Berdasarkan Tabel 1, terlihat terjadi peningkatan dari pra siklus ke siklus I dan ke siklus II, baik pada rata-rata maupun rata-rata persen. Dengan demikian penerapan metode demonstrasi berbantuan media sederhana dapat meningkatkan hasil belajar tematik (muatan Matematika) siswa kelas III SD Negeri 2 Kampung Baru semester I tahun pelajaran 2019/2020.

Pada prasiklus, hasil belajar menunjukkan sebesar 64, rata-rata persen sebesar 64\% dengan kriteria kurang. Hasil belajar ini menunjukkan bahwa mata pelajaran Matematika menjadi salah satu mata pelajaran yang membosankan, ditakuti dan kurang diminati, serta berpusat kepada guru, siswa hanya berperan sebagai pendengar dan penerima semua informasi yang diberikan oleh guru. Sementara dari pihak guru yang dinilai enggan menggunakan media atau alat peraga dalam menyampaikan materi pelajaran, terlebih lagi jika media atau alat peraga tersebut tidak tersedia di sekolah.

Pada siklus I, hasil belajar menunjukkan sebesar 73.33, rata-rata persen sebesar $73.33 \%$ dengan kriteria cukup. Hasil belajar ini telah menunjukkan perbaikan hasil belajar dibandingkan dengan hasil belajar sebelumnya. Adapun Kelemahan atau hambatan yang ditemui dalam siklus I adalah dalam mengerjakan tugas dan latihan, siswa belum terlihat mengerjakan tugas dengan sungguh-sungguh. Siswa yang belum mengerti tidak berani bertanya kepada guru, mereka menunggu jawaban dari temannya yang sudah selesai mengerjakan tugas. Solusi yang ditempuh adalah memberikan pemahaman kepada siswa, bahwa guru siap memberikan penjelasan apabila siswa belum mengerti dalam mengerjakan tugas dan memberikan motivasi kepada siswa agar hasil belajarnya dapat meningkat. 
Pada siklus II, hasil belajar menunjukkan sebesar 78.67, rata-rata persen sebesar 78.67\% dengan kriteria baik. Adapun keunggulan dalam proses pembelajaran di siklus II adalah siswa tampak tertarik pada saat guru mendemonstrasikan materi, siswa mulai berani bertanya kepada guru tentang tugas yang diberikan. Siswa sudah mulai bisa berkomunikasi dengan baik pada saat bertanya dan mempresentasikan hasil kerja kelompok mereka. Dengan demikian penerapan metode demonstrasi berbantuan media sederhana dapat meningkatkan hasil belajar siswa. Hasil analisis data menunjukkan peningkatan hasil belajar siswa. Pada pra siklus persentase hasil belajar siswa sebesar 64,00\% yang tergolong kurang, siklus I persentase hasil belajar siswa sebesar 73,33\% yang tergolong cukup, meningkat pada siklus II menjadi 78,67\% yang tergolong baik dan telah melampaui indikator keberhasilan penelitian yaitu 75\%. Hasil belajar merupakan suatu hasil belajar yang dapat merefleksikan tentang suasana yang diciptakan oleh guru, sarana atau fasilitas dan pendekatan yang dipergunakan terhadap metode yang digunakan dalam proses pembelajaran, sehingga dapat meningkatkan proses belajar siswa dan bermuara pada peningkatan hasil belajar siswa.

Pada penelitian ini proses pembelajaran dilaksanakan dengan menerapkan metode demonstrasi berbantuan media sederhana. Pada proses pembelajaran siswa termotivasi untuk aktif pada kegiatan mengamati demonstrasi guru terkait materi dan mengerjakan tugas yang diberikan dengan bimbingan guru, sehingga siswa dapat memahami materi pembelajaran dengan lebih baik dan hasil belajarpun meningkat. Peningkatan ini menunjukkan bahwa penerapan metode demonstrasi berbantuan media sederhana dapat meningkatkan hasil belajar tematik (muatan Matematika) siswa kelas III SD Negeri 2 Kampung Baru semester I tahun pelajaran 2019/2020. Metode demonstrasi adalah cara penyajian bahan pelajaran dengan memperagakan atau mempertunjukkan kepada siswa suatu proses, situasi, atau benda tertentu yang sedang dipelajari baik sebenarnya maupun tiruan, yang sering disertai penjelasan lisan (Nahdi et al., 2018; Nurmitasari, 2016; Rizkiana et al., 2016). Selain itu metode demonstrasi dapat dikatakan sebagai suatu metode mengajar yang memperlihatkan tentang sesuatu disertai penjelasan lisan, siswa melihat dan mengamati sehingga memperoleh gambaran yang jelas. Tujuan penerapan metode demonstrasi adalah untuk mendapatkan gambaran yang jelas tentang hal-hal yang berhubungan dengan proses mengatur sesuatu, proses membuat sesuatu, proses bekerjanya sesuatu, proses mengeijakan atau menggunakannya, komponen-komponen yang membentuk sesuatu, membandingkan suatu cara dengan cara lain dan untuk mengetahui atau melihat kebenaran sesuatu (Annisa et al., 2014; Netriza, 2019; Purwanti, 2018). Kelebihan metode demonstrasi meliputi: (1) dapat membuat pengajaran menjadi lebih jelas dan lebih konkret, sehingga dapat menghindari verbalisme (pemahaman secara kata-kata atau kalimat); (2) siswa lebih mudah memahami apa yang dipelajari; (3) proses pengajaran lebih menarik; (4) siswa dirangsang untuk aktif mengamati, menyesuaikan antara teori dengan kenyataan dan mencoba melakukan sendiri. Metode demonstrasi akan lebih efektif digunakan jika dilengkapi dengan penggunaan media sederhana (Andriansyah, 2020; Masduri, 2014; Srininsih, 2015).

Media sederhana merupakan media yang bahan dasarnya mudah diperoleh, harganya murah, pembuatannya mudah, dan penggunaannya tidak sulit (Bahtiar, 2019; Sari et al., 2019; Ulya \& Rofian, 2019). Selain itu, media sederhana dapat diartikan sebagai media pembelajaran yang memiliki perbed aan karakteristik dan tidak bisa digolongkan ke dalam pembelajaran visual ataupun audio-visual. Media sederhana tergolong murah dan tidak rumit, sehingga pengadaannya dapat dikembangkan sendiri oleh guru, walaupun begitu media pembelajaran sederhana tidak berarti lebih rendah kualitasnya dibandingkan dengan media pembelajaran yang mengunakan teknologi canggih.

Media yang dipergunakan dalam penelitian ini adalah media sederhana, karena merupakan media yang mudah diperoleh dan harganya murah, cara pembuatannya mudah, dan penggunaannya tidak sulit (Anggrain \& Veronica, 2015; Mudarini, 2017; Wicaksono et al., 2020). Di lingkungan sekolah banyak tersedia media sederhana, tetapi diperlukan kejelian guru untuk memilah dan memilih media yang tepat sesuai dengan tujuan pembelajaran. Media sederhana yang digunakan pada penelitian ini adalah kartu bilangan, kerikil, manik-manik, tangkai es krim, pensil, dan benda-benda yang ada di sekitar. Penggunaan media pembelajaran ini diharapkan dapat membantu dalam meningkatkan hasil belajar siswa.

Penelitian tindakan kelas ini tentang penerapan metode demontrasi berbantuan media sederhana, didukung dengan beberapa penelitian sebelumnya yang relevan yaitu, pertama penelitian yang dilaksanakan oleh (Rizkiana et al., 2016), yang mendapatkan hasil bahwa praktikum dan Metode Demonstrasi dalam pembelajaran inkuiri terbimbing berpengaruh terhadap motivasi belajar siswa. Kedua, penelitian yang dilaksanakan oleh (Nahdi et al., 2018), yang mendapatkan hasil bahwa penerapan Metode Demonstrasi pada mata pelajaran IPA berpengaruh terhadap pemahaman konsep siswa. Ketiga, penelitian yang dilaksanakan oleh (Masduri, 2014), yang mendapatkan hasil adalah penerapan kolaborasi Metode Demonstrasi dan eksperimen terbukti berpengaruh terhadap pemahaman konsep sifat-sifat bangun ruang. 
Implikasi penelitian ini adalah dapat membuat pengajaran menjadi lebih jelas dan lebih konkret, siswa lebih mudah memahami materi, proses pengajaran lebih menarik, siswa dirangsang untuk aktif mengamati, menyesuaikan antara teori dengan kenyataan dan melatih siswa untuk berani mencoba.

\section{Simpulan}

Berdasarkan analisis data dan pembahasan hasil penelitian yang telah diuraikan, maka dapat diambil simpulan bahwa penerapan metode demonstrasi berbantuan media sederhana dapat meningkatkan hasil belajar tematik (muatan Matematika) siswa kelas III SD Negeri 2 Kampung Baru semester I tahun pelajaran 2019/2020. Implikasi penelitian ini adalah dapat membuat pengajaran menjadi lebih jelas dan lebih konkret, siswa lebih mudah memahami materi, proses pengajaran lebih menarik, siswa dirangsang untuk aktif mengamati, menyesuaikan antara teori dengan kenyataan dan melatih siswa untuk berani mencoba.

\section{Daftar Rujukan}

Andriansyah, E. H. (2020). Mengembangkan Sikap Positif dan Pemahaman Siswa Melalui Pembelajaran Kontekstual dengan Metode Demonstrasi atau Field Trip. Pedagogia: Jurnal Pendidikan, 9(1), 8189. https://doi.org/10.21070/pedagogia.v9i1.270

Anggrain, D., \& Veronica, R. B. (2015). Keefektifan Pembelajaran Core Berbantuan Kartu Kerja Pada Pencapaian Kemampuan Masalah Matematika Dan Kepercayaan Diri Siswa Kelas VIII. Unnes Journal of Mathematics Education, 4(3), 1-9. https://doi.org/10.15294/ujme.v4i2.8497

Anisah, \& Lastuti, S. (2018). Pengembangan Bahan Ajar berbasis HOTS untuk Meningkatkan Kemampuan Pemecahan Masalah Matematis Mahasiswa. Kreano: Jurnal Matematika Kreatif-Inovatif, 9(2), 191197. https://doi.org/10.15294/kreano.v9i2.16341

Annisa, F. N., Karim, S., \& Aminudin, A. (2014). Penerapan Metode Pembelajaran Demonstrasi Interaktif Untuk Meningkatkan Hasil Belajar Fisika Siswa SMA Pada Konsep Suhu Dan Kalor. Jurnal Pengajaran Mipa, 19(1), 88-93. https://doi.org/10.18269/jpmipa.v19i1.429

Asnita, A. U. (2016). Perbandingan Hasil Belajar Matematika Melalui Metode Inquiri Terbimbing Dan Metode Pq4r (Preview, Question, Read, Reflect, Recite, Review) Pada Siswa Kelas VII SMP Negeri 1 Sinjai Tengah. Mapan: Jurnal Matematika Dan Pembelajaran, 4(1), 144 - 155. https://doi.org/10.24252/mapan.2016v4n1a10

Bahtiar, R. S. (2019). Efektivitas Penggunaan Media Papan Waktu Pada Pembelajaran Penghitungan Waktu Bagi Siswa Kelas III Sekolah Dasar. Jurnal Bidang Pendidikan Dasar, 3(1), 14-23. https://doi.org/10.21067/jbpd.v3i1.2857

Cahyaningsih, U. (2018). Penerapan Model Pembelajaran Kooperatif Tipe TAI (Team Assisted Individualization) Untuk Meningkatkan Hasil Belajar Siswa Pada Mata Pelajaran Matematika. Jurnal Cakrawala Pendas, 4(1). https://doi.org/10.31949/jcp.v4i1.707

Citrasmi, N. W., Wirya, N., \& Tegeh, I. M. (2016). Pengaruh Model Pembelajaran Scramble Berbantuan Media Gambar Terhadap Hasil Belajar IPA DI SD. Jurnal Mimbar PGSD Undiksha, 4(2). https://doi.org/10.23887/jjpgsd.v4i2.8425

Dewiyanti, N. K. (2018). Pengaruh Model Pembelajaran Team Games Tournament (TGT) Berbantuan Media Permainan Ular Tangga terhadap Hasil Belajar Matematika. Jurnal Imiah Pendidikan Dan Pembelajaran, 2(1). https://doi.org/10.23887/jipp.v2i1.13977

Elinawati, W., Duda, H. J., \& Julung, H. (2018). Penerapan Model Pembelajaran Auditory, Intellectually, Repetition (Air) terhadap Hasil Belajar Matematika Siswa. Jurnal Sainsmat, 7(1), 13-24. https://doi.org/10.31539/judika.v2i1.701

Handayani, I. M., Pujiastuti, E., \& Suhito. (2014). Keefektifan Auditory Intellectually Repetition Berbantuan LKPD terhadap Kemampuan Penalaran Peserta Didik SMP. Kreano: Jurnal Matematika KreatifInovatif, 5(1), 1-9. https://doi.org/10.15294/kreano.v5i1.3271

Latifah, \& Nurlaeli. (2017). Pengaruh Penerapan Model Pembelajaran Auditory, Intellectually, Repetition (AIR) Terhadap Hasil Belajar Siswa Pada Mata Pelajaran Matematika Materi Pembagian di Kelas IV MIN Gebang Udik Kecamatan Gebang Kabupaten Cirebon. Al Ibtida: Jurnal Pendidikan Guru MI, 4(1), 97-108. https://doi.org/10.24235/al.ibtida.snj.v4i1.1474

Mariani. (2017). Penerapan Model Pembelajaran Make A Match Untuk Meningkatkan Hasil Belajar Matematika Tentang Pembagian Pada Siswa Kelas II SD Muhammadiyah 4 Batu. JINoP Jurnal Inovasi Pembelajaran), 3(2), 599. https://doi.org/10.22219/jinop.v3i2.5306

Masduri, M. (2014). Memahami Konsep Matematika Pada Materi Sifat-Sifat bangun Ruang Pada Kelas VB Melalui Kolaborasi Metode Ceramah Demonstrasi dan Eksperimen. Pedagogia: Jurnal Pendidikan, 
3(2), 127-135. https://doi.org/10.21070/pedagogia.v3i2.64

Maufur, S., \& Lisnawati, S. (2017). Pengaruh Penggunaan Media Gambar Berseri Terhadap Keterampilan Berbicara Bahasa Indonesia Siswa Kelas III MI Al-Washliyah Perbutulan Kabupaten Cirebon. Al Ibtida: Jurnal Pendidikan Guru MI, 4(2), 189. https://doi.org/10.24235/al.ibtida.snj.v4i2.1888

Mudarini, dkk H. (2017). Pengaruh Pembelajaran Student Facilitator And Explaining (SFAE) Berbantuan Media Kartu Terhadap Hasil Belajar IPA Siswa. Jurnal Mimbar PGSD Universitas Pendidikan Ganesha, 5(2), 1-11. https://doi.org/10.23887/jjpgsd.v5i2.11016

Nahdi, D. S., Yonanda, D. A., \& Agustin, N. F. (2018). Upaya Meningkatkan Pemahaman Konsep Siswa Melalui Penerapan Metode Demonstrasi Pada Mata Pelajaran IPA. Jurnal Cakrawala Pendas, 4(2), 9-16. https://doi.org/10.31949/jcp.v4i2.1050

Netriza, N. (2019). Penerapan Metode Demonstrasi Untuk Meningkatkan Kemampuan Shalat Siswa Kelas III SD Negeri 003 Pulau Permai Kecamatan Tambang Kabupaten Kampar. Jurnal Pajar (Pendidikan Dan Pengajaran), 3(1), 166-174. https://doi.org/10.33578/pjr.v3i1.6482

Nurhazannah, Y. (2017). Meningkatkan Hasil Belajar Siswa Menggunakan Model Pembelajaran Kooperatif Tipe StudentTeam Achievement Devision (STAD). Jurnal Pendidikan Matematika Dan IPA, 8(2), 50-59. https://doi.org/10.26418/jpmipa.v8i2.21176

Nurmitasari. (2016). Pembelajaran Lingkaran dengan Metode Demonstrasi Melalui Alat Peraga Konkrit dan Alat Peraga Gambar. E-DuMath, 2(1), 170-178. https://doi.org/10.26638/je.170.2064

Pramana, I. N. I., Suwatra, I. I. W., \& Sedanayasa, G. (2014). Pengaruh Model Pembelajaran Kooperatif Tipe TAI (Team Assisted Individualization) Dan Yang Konvensional Terhadap Hasil Belajar Matematika Kelas IV DI SD Wongaya Gede Tahun Pelajaran 2012/2013. Mimbar PGSD Undiksha, 2(1). https://doi.org/10.23887/jjpgsd.v2i1.4540

Purwanti, T. (2018). Peningkatan Keterampilan Penjumlahan Bilangan Bulat Dengan Metode Demonstrasi Dan Media Garis Bilangan Kelas IV SD Negeri 2 Geneng Kecamatan Batealit Kabupaten Jepara. Jurnal Ilmiah Pendidikan Dasar, 5(1), 11-17. https://doi.org/10.30659/pendas.5.1.11-17

Putri, A., Sumardani, D., Rahayu, W., \& Hajizah, M. N. (2020). Kemampuan Berpikir Kritis Matematis Menggunakan Model Generative Learning Dan Connecting, Organizing, Reflecting, Extending (Core). Aksioma: Jurnal Program Studi Pendidikan Matematika, 9(1), 108-117. https://doi.org/10.24127/ajpm.v9i1.2617

Rahmadani, Y., Tayeb, T., \& Baharuddin. (2018). Modul Matematika Berbasis Model Kooperatif Tipe STAD Dengan Metode Penemuan Terbimbing Pada Pokok Bahasan Teorema Phytagoras. Lentera Pendidikan: Jurnal Ilmu Tarbiyah Dan Keguruan, 21(1), 23-32. https://doi.org/10.24252/lp.2018v21n1i3

Rizkiana, F., Dasna, I. W., \& Marfu'ah, S. (2016). Pengaruh Praktikum Dan Demonstrasi Dalam Pembelajaran Inkuiri Terbimbing Terhadap Motivasi Belajar Siswa Pada Materi Asam Basa Ditinjau Dari Kemampuan Awal. Jurnal Pendidikan: Teori, Penelitian, Dan Pengembangan, 1(3), 354 - 362. https://doi.org/10.17977/jp.v1i3.6161

Sari, N. L. S. D., Sudana, D. N., \& Parmiti, D. P. (2019). Pengaruh VCT Berbantuan Media Sederhana Terhadap Hasil Belajar PKN. Journal of Education Technology, 3(2), 49-57. https://doi.org/10.23887/jet.v3i2.21701

Sopia, H. F., \& Wutsqa, D. U. (2015). Keefektifan Pendekatan Realistik Ditinjau dari Prestasi Belajar, Kemampuan Pemecahan Masalah, dan Kepercayaan Diri Matematika. Pythagoras: Jurnal Pendidikan Matematika, 10(2), 146-154. https://doi.org/10.21831/pg.v10i2.9139

Srininsih, E. (2015). Penerapan Teknik Vokal yang Baik dan Benar dengan Menggunakan Metode Demonstrasi untuk Meningkatkan Kemampuan Bernyanyi Mata Pelajaran Seni Budaya pada Siswa Kelas VII Bilingual di SMPN 4 Mataram. Jurnal Kependidikan, 1(2). https://doi.org/10.33394/jk.v1i2.416

Ulfah, D. M., \& Soenarto, S. (2017). Pengaruh penggunaan media video dan gambar terhadap keterampilan menulis kelas V. Jurnal Prima Edukasia, 5(1), 22-34. https://doi.org/10.21831/jpe.v5i1.7693

Ulya, H., \& Rofian, R. (2019). Pengembangan Media Story Telling Berbasis Montase Sederhana Sebagai Suplemen Bahan Ajar Tema Peduli Terhadap Makhluk Hidup Kelas IV Sekolah Dasar. Jurnal Pendidikan Dasar Nusantara, 5(1), 140-149. https://doi.org/10.29407/jpdn.v4i2.12166

Wicaksono, A. G., Jumanto, \& Oka, I. (2020). Pengembangan media komik komsa materi rangka pada pembelajaran IPA di sekolah dasar. Premiere Educandum: Jurnal Pendidikan Dasar Dan Pembelajaran, 10(2), 215-226. https://doi.org/10.25273/pe.v10i2.6384 